\title{
Improving Students' Scientific Reasoning Skills through the Three Levels of Inquiry
}

\section{Bagus Endri Yanto}

Student of Post-Graduate Educational Sciences, Yogyakarta State University, Yogyakarta, Indonesia, bagus.endri2015@student.uny.ac.id

\section{Bambang Subali}

Prof., Faculty of Mathematics and Natural Sciences, Yogyakarta State University, Yogyakarta, Indonesia, bambangsubali@uny.ac.id

\section{Slamet Suyanto}

Faculty of Mathematics and Natural Sciences, Yogyakarta State University, Yogyakarta, Indonesia, slametsuyanto@yahoo.com

$$
\text { . }
$$

This research was aimed at analyzing (1) the effectiveness of the three levels of inquiry (structured, guided and free inquiry) to improve the students' scientific reasoning skills compared to the conventional method; (2) the implementation of the three levels of inquiry. This study can be categorized as quasi-experimental with pre-test posttest non-equivalent control group design. The research sample consisted of 76 students of the Biology Education Study Program in State Islamic University of Sunan Kalijaga, Yogyakarta, Indonesia. The data were collected by using scientific reasoning test and an observation sheet. The data were analyzed with the independent sample t-test. The research results indicated that the three levels of inquiry were more effective than the conventional method in improving the students' scientific reasoning skills in the aspects of analyzing, evaluating, and creating. The quality of three levels of inquiry can be categorized as very good. It urges biology lecturers to have a comprehensive understanding of the hierarchical nature and its relationship to various pedagogical practices to employ investigation process during the science learning process.

Keywords: scientific reasoning, analyzing, evaluating, creating, the three levels of inquiry, biology education students

\section{INTRODUCTION}

To enhance the students' learning achievement, it must be supported with creative ways of teaching, especially for sciences learning. It urges the science education to implement 
more relevant and innovative method so that the students can develop their reasoning process through inquiry methods by involving cognitive and metacognitive activities to support their logical thinking (Martin-Gamez et al., 2016; Makarova et al, 2017; Osborne \& Kind, 2017). The implementation of inquiry model is important to develop students' thinking competence and the science teachers should have good teaching strategies to provide meaningful learning experiences with the inquiry method (Utomo et al., 2018; Ketpichainarong et al., 2010; Andrini, 2016). Several studies show that the implementation of inquiry strategy is more effective than the traditional method since it has a significant effect to improve the students' learning performance, motivation, creative thinking as well as concepts mastery (Sahyar \& Hastini, 2017; Yanto, 2016; Artayasa et al., 2018; Arsal, 2017; Uum et al., 2017). Some researchers explain that the learning process should be able to develop the students' logical reasoning through creative and analytical investigation as well as to improve the students' problem-solving skills (Thummathong \& Thathong, 2016; Ary et al., 2010; Steinberg \& Cormier, 2013). In university level, the learning functions to form and develop all potential competence for scientific reasoning. The definitions of reasoning are diverse according to some experts. Partanto \& Al Barry, 1994; Bruner (in Lohman \& Lakin, 2011) mention reasoning as a thinking process to draw conclusions based on the factual information. Meanwhile, Shaw (2010) defines the process of reasoning including the linking of evidence and facts to construct logical conclusions. From those definitions, it can be concluded that scientific reasoning is important to be applied in the learning process to train the students' critical thinking and decisions making.

The reasoning process integrates the reciprocal relationships among various variables in a comprehensive way of thinking. In this case, science teaching emphasizes the importance of reasoning skills, such as generating hypotheses, evaluating evidence and formulating conclusions through a practical process of knowledge transfer under the teacher instruction (Opitz et al., 2017; Novkovic-Cvetkovic \& Stanojevic, 2017). Based on several findings of current scientific studies on reasoning show its positive impact to improve students' learning outcomes (Moore \& Rubbo, 2012; Nieminen et al., 2012; Stephans \& Clement, 2010; Marusic et al., 2012; Jeong et al., 2014; Steinberg \& Cormier, 2013). The competence of scientific reasoning has also become a crucial aspect for higher level of education by employing the sequence of inquiry learning (Alameddinea \& Ahwalb, 2016; Mäeots \& Pedaste, 2014; Wenning, 2011).

Based on the results of Programme for International Students Assessment in 2015, the scientific literacy skills of Indonesian students rank below the average from 44 countries (OECD, 2016). The low achievements is presumably caused by the learning process that is still oriented to low-order thinking skills and lack of scientific reasoning activities. It makes the students from high school graduates who are now in higher education level still possess low thinking ability. Therefore, the application of three levels of inquiry to improve scientific reasoning should be realized. Furthermore, the results of a pilot study among the universities in Yogyakarta revealed some problems concerning biology learning, such as the lack application of inquiry learning and training (Yanto, et al., 2019). This pilot study was then supported by the research results from Saptono et al., (2013), Asniar (2016) and Probosari et al., (2015) where the lecturing activities 
emphasize more on remembering and practicum. It makes most of the students were lack of ability to use scientific reasoning skills, thinking analysis, arguing. This condition shows the urgency to implement the scientific reasoning during the learning process.

The scientific reasoning in this research refers to a rational thinking process based on analyses, evaluation, and creation, as the aspects of the reasoning competence. This study applies three levels of inquiry, namely, structured, guided and open inquiry, to enhance the students' scientific reasoning competency levels to analyze, evaluate, and create based on contextual issues. The learning activity is done by using the syntax of inquiry learning through the stages of problem orientation, problem formulation, problem exploration, investigation, and conclusion. This study is supported by the results from Zion and Mendelovici (2012), Llewellyn (2013) and Arslan (2014), that the three inquiry models have significant effects on increasing the students' learning outcomes. According to Zubaidah et al., (2017), there are many obstacles if it only uses one level of inquiry for a particular topic without accommodating the level of the students' development. The objective of this research is to examine the effects of the three levels of inquiry to improve the students' scientific reasoning competence. Based on the theoretical review and relevant studies, the research question can be formulated as follows: (1) How is the effectiveness of the three levels of inquiry to improve the students' scientific reasoning skill compared to the conventional method? (2) How is the applied model of structured, guided and free inquiry to improve the students' scientific reasoning skill in Biology education?

\section{METHOD}

\section{Research Design}

This research can be categorized as quasi experimental design in order to measure the improvement of the students' scientific reasoning through pretest-posttest, Nonequivalent control group design. The experimental group was given the treatment of the structured, guided and open inquiry. Another class was the conventional group, which was used as the control group with the conventional method. The procedure for the three levels of inquiry based on the level of the students' development and the lecturer's involvement in applying the learning syntax of the three level of inquiry. 
Table 1

The Procedure for the Three Levels of Inquiry based on the Level of Students' Development

\begin{tabular}{|c|c|c|c|c|}
\hline $\begin{array}{l}\text { Stages of } \\
\text { learning }\end{array}$ & Structured inquiry & Guided inquiry & free inquiry & Conventional \\
\hline $\begin{array}{l}\text { Problem } \\
\text { formulation }\end{array}$ & $\begin{array}{l}\text { The lecturers } \\
\text { formulate problems, } \\
\text { and the students } \\
\text { were given } \\
\text { experiment questions } \\
\text { and formulated } \\
\text { hypotheses }\end{array}$ & $\begin{array}{l}\text { The lecturers } \\
\text { formulate problems, } \\
\text { and the students } \\
\text { were given } \\
\text { experiment questions } \\
\text { and formulated } \\
\text { hypotheses }\end{array}$ & $\begin{array}{l}\text { The students } \\
\text { formulated } \\
\text { experiment } \\
\text { questions and } \\
\text { hypotheses }\end{array}$ & $\begin{array}{l}\text { The students } \\
\text { are given }\end{array}$ \\
\hline Exploration & $\begin{array}{l}\text { The students } \\
\text { looking for needed } \\
\text { information to test } \\
\text { hypotheses }\end{array}$ & $\begin{array}{l}\text { The student looking } \\
\text { for needed } \\
\text { information to test } \\
\text { hypotheses }\end{array}$ & $\begin{array}{l}\text { The student } \\
\text { looking for needed } \\
\text { information to test } \\
\text { hypotheses }\end{array}$ & $\begin{array}{l}\text { questions, } \\
\text { procedures and } \\
\text { solutions to } \\
\text { problems that } \\
\text { at the }\end{array}$ \\
\hline Investigation & $\begin{array}{l}\text { The students } \\
\text { conducted } \\
\text { experiments based } \\
\text { on the working } \\
\text { procedures made by } \\
\text { the lecturers }\end{array}$ & $\begin{array}{l}\text { The students } \\
\text { conducted } \\
\text { experiments based } \\
\text { on their own } \\
\text { working procedure }\end{array}$ & $\begin{array}{l}\text { The students } \\
\text { conducted } \\
\text { experiments based } \\
\text { on their own } \\
\text { working procedure } \\
\text { The students }\end{array}$ & $\begin{array}{l}\text { beginning. The } \\
\text { lecturer guided } \\
\text { the inquiry } \\
\text { process to } \\
\text { provide all } \\
\text { information }\end{array}$ \\
\hline Conclusion & $\begin{array}{l}\text { The students } \\
\text { formulated } \\
\text { conclusions based on } \\
\text { data collection }\end{array}$ & $\begin{array}{l}\text { The students } \\
\text { formulated } \\
\text { conclusions based on } \\
\text { data collection }\end{array}$ & $\begin{array}{l}\text { formulated } \\
\text { conclusions based } \\
\text { on data collection }\end{array}$ & \\
\hline
\end{tabular}

This research was conducted for two months from February to March, 2018. In the first lesson, it was implemented the lowest level of inquiry, i.e. the structured inquiry, the second lesson was a higher level of inquiry, the guided inquiry, and the third lesson was free inquiry. There were three topics of science that students learned during this study, namely, plant nutrients, respiration and seed germination. The inquiry classes and the conventional classes discussed those three topics. The learning was conducted once a week with 120 minutes for each meeting.

The learning process of the three levels of inquiry and traditional classes has different characteristics. The students in the structured inquiry class formulated hypotheses, conducted experiments by following the working procedures from the lecturers and then, formulated conclusions based on data collection. The students in the guided inquiry class were given several experiment questions, but they were instructed to create their own working procedure. In the free inquiry class, the students formulated experiment questions, hypotheses, and carried out the experiment based on the questions. Meanwhile, the conventional class carried out the experiment based on the lecturer's complete instructions including the experiment questions, working procedures, and its solutions. The lecturer guided the inquiry process by providing all information 


\section{Participants and Research Sample}

The population in this study was all students of Biology education study program. The subjects of this research were 76 students of the fourth semester of biology education in State Islamic University of Sunan Kalijaga, Yogyakarta, Indonesia in the academic year of 2017/2018. There were 38 students in each group of experimental and control. The sampling technique employed cluster sampling to determine the sample with groups instead of individuals as sample units. The implementation of the three inquiry strategies and the conventional method was the independent variable, while the scientific reasoning skills of the analyzing, evaluating and creating aspects as the dependent variable.

\section{Data Collection and Analysis}

The instruments of this study were using the observation sheet and the essay-test. After the instruments were made, it was then reviewed and validated by five experts of education. The total of nine test items was used on the pre-test and post-test. All the instruments items were valid with the sensitivity index items of .70 (Grounlund, 1992), while the validity of the observation sheet examined with the Aiken index in which each item obtained .93 which can be categorized as very high (Guilford, 1956). The coefficient Cohen's Kappa ( $\kappa)$ was .74 . for the test instrument and .73 for the observation sheets. Thus, it can be declared as reliable (Linn, 1989). The observation sheets were to reveal the suitability level of the learning activities for inquiry learning done by the lecturers. This observation was carried out based on the following indicators: problem orientation, problems formulation, hypotheses formulation problem, information search through learning resources, monitor and guide students in conducting investigations and directing to formulate conclusions. The instrument of test was an essay-type test with the answer criteria consisting of three categories. The score of the essay was between 0,1 and 2 (Brookhart, 2010). Table 2 presents a grid of the scientific reasoning abilities.

Table 2

The Grid for Scientific Reasoning Skills Test Instrument

\begin{tabular}{|c|c|c|c|}
\hline Aspect & Material & Indicator & $\begin{array}{l}\text { Item } \\
\text { Number }\end{array}$ \\
\hline \multirow[t]{3}{*}{ Analyzing } & $\begin{array}{l}\text { Nutrients of } \\
\text { plants }\end{array}$ & $\begin{array}{l}\text { Distinguishing relevant sections of } \\
\text { factual objects, }\end{array}$ & 1 \\
\hline & & 1. Analyzing the relationship among variables & 2 \\
\hline & & $\begin{array}{l}\text { Describing the causal relationship } \\
\text { of a phenomenon }\end{array}$ & 1 \\
\hline \multirow[t]{2}{*}{ Evaluating } & Seed & . Reviewing factual statements critically & 1 \\
\hline & germination & $\begin{array}{l}\text { Testing the validity of the procedure based } \\
\text { on data collection. }\end{array}$ & 1 \\
\hline \multirow[t]{3}{*}{ Creating } & Respiration & .. Designing scientific procedures & 1 \\
\hline & & 1. Formulating hypothesis & 1 \\
\hline & & $\therefore$ Formulating a conclusion & 1 \\
\hline
\end{tabular}


The data were analyzed descriptive quantitative with Statistical Package for Social Sciences (SPSS) for Windows version 22. The One-Sample Kolmogorov-Smirnov test was performed to determine the normality of the data and Levene test was performed to examine the homogeneity. The independent sample t-test was performed to determine the significance difference in the mean score of the two implemented strategies.

\section{FINDINGS}

\section{Scientific Reasoning Increasing of Analyzing Aspect}

The results showed that the analyzing competence with the structured inquiry strategy was higher than the conventional method. The structured inquiry obtained the average pre-test score of 10.94 and post-test of 82.23 , while the conventional strategy received 9.00 for the pre-test and 31.76 for the post-test (Table 3 ).

Table 3

Description of Analyzing Competence

\begin{tabular}{|c|c|c|c|c|c|c|c|c|c|}
\hline \multirow[b]{2}{*}{ Variable } & \multirow[b]{2}{*}{ Stat. } & \multicolumn{4}{|c|}{ Structured Inquiry } & \multicolumn{4}{|c|}{ Conventional Teaching } \\
\hline & & $\mathrm{n}$ & $\begin{array}{l}\text { Pre- } \\
\text { test }\end{array}$ & $\begin{array}{l}\text { Post- } \\
\text { test }\end{array}$ & $\mathrm{N}<\mathrm{G}\rangle$ & $\mathrm{n}$ & $\begin{array}{l}\text { Pre- } \\
\text { test }\end{array}$ & $\begin{array}{l}\text { Post- } \\
\text { test }\end{array}$ & $\mathrm{N}<\mathrm{G}>$ \\
\hline \multirow{3}{*}{$\begin{array}{l}\text { Analyzing } \\
\text { competence }\end{array}$} & $\overline{\bar{x}}$ & \multirow[t]{3}{*}{38} & 10.94 & 82.23 & \multirow[t]{3}{*}{.80} & \multirow[t]{3}{*}{38} & 9.00 & 31.76 & \multirow[t]{3}{*}{.25} \\
\hline & $\%$ & & 25 & 100 & & & 25 & 75 & \\
\hline & $\mathrm{s}$ & & 1.46 & 1.97 & & & 1.45 & 1.82 & \\
\hline
\end{tabular}

The results of Kolmogorov-Smirnov One-Sample test indicated that both pre-test and post-test had significant values of $p=.308>.05$, so that the scores of both tests were not normally distributed. The homogeneity test with Levene revealed the score of homogeneous variances $(p>.05)$ in which the value for the pretest was .580 and the post-test was .729 , respectively. The result of independent sample t-test with equal variances assumed (Table 4) showed that the structured inquiry and the conventional strategy had different mean score significantly. It indicated the effect of the structured inquiry implementation toward the improvement of the students' analyzing competence $(p=.00<.05)$. It can be seen from Asymp. Sig. (2-tailed) of .010 in pretest and .000 in posttest with $(\mathrm{p}=.000<.05)$. So, it can be concluded that the average of analyzing competency with structured inquiry learning is higher than the implementation of the conventional teaching.

Table 4

The Result of Independent Sample T-Test for the Analyzing Competence

\begin{tabular}{lll}
\hline Group & $\mathrm{t}$ & Asymp. Sig. (2-Tailed) \\
\hline Pretest Experiment Control & 942 & .010 \\
\hline Posttest Experiment Control & 18.753 & .000 \\
\hline
\end{tabular}

\section{Scientific Reasoning Increasing of Evaluating Aspect}

The results showed that the evaluating competence with the guided inquiry was higher than the conventional strategy. The guided inquiry strategy obtained the average pre-test 
score of 11.55 and post-test of 85.42 , while the conventional strategy had 9.31 for the pre-test and 34.23 for the post-test (Table 5).

Table 5

Description of the evaluating competence

\begin{tabular}{|c|c|c|c|c|c|c|c|c|c|}
\hline \multirow[b]{2}{*}{ Variable } & \multirow[b]{2}{*}{ Stat. } & \multicolumn{4}{|c|}{ Guided Inquiry } & \multicolumn{4}{|c|}{ Conventional Teaching } \\
\hline & & $\mathrm{n}$ & $\begin{array}{l}\text { Pre- } \\
\text { test }\end{array}$ & $\begin{array}{l}\text { Post- } \\
\text { test }\end{array}$ & $\mathrm{N}<\mathrm{G}>$ & $\mathrm{n}$ & $\begin{array}{l}\text { Pre- } \\
\text { test }\end{array}$ & $\begin{array}{l}\text { Post- } \\
\text { test }\end{array}$ & $\mathrm{N}<\mathrm{G}>$ \\
\hline \multirow{3}{*}{$\begin{array}{l}\text { Evaluating } \\
\text { competence }\end{array}$} & $\overline{\bar{x}}$ & \multirow[t]{3}{*}{38} & 11.55 & 85.42 & \multirow[t]{3}{*}{.83} & \multirow[t]{3}{*}{38} & 9.31 & 34.23 & \multirow[t]{3}{*}{.27} \\
\hline & $\%$ & & 25 & 100 & & & 25 & 75 & \\
\hline & $\mathrm{s}$ & & 1.32 & 1.50 & & & 1.43 & 2.23 & \\
\hline
\end{tabular}

The results of Kolmogorov-Smirnov One-Sample test indicated that both pre-test and post-test had significant values of $p=.183>.05$, so that the scores of both tests were not normally distributed. The homogeneity test with Levene test revealed the score of homogeneous variance $(p>.05)$ where the value for the pretest was .135 and the posttest was .216, respectively. The result of independent sample t-test with equal variances assumed (Table 6) showed that the guided inquiry and conventional strategy gained different mean score significantly. It indicated the effect of the guided inquiry implementation toward the improvement of the students' evaluating competence ( $p=.00$ $<.05)$. It can be seen from Asymp. Sig. (2-tailed) of .256 in pretest value, and .000 in posttest with $(\mathrm{p}=.000<.05)$. So, it can be concluded that the average of evaluating competency with guided inquiry learning is higher than the conventional teaching.

Table 6

The Result of Independent Sample T-Test for the Evaluating Competence

\begin{tabular}{lll}
\hline Group & $\mathrm{t}$ & Asymp. Sig. (2-Tailed) \\
\hline Pretest Experiment Control & 1.144 & .256 \\
\hline Posttest Experiment Control & 18.481 & .000 \\
\hline
\end{tabular}

\section{Improvement of Scientific Reasoning for Creating Aspect}

The results showed that the creating competence with the free inquiry was higher than the conventional strategy. The free inquiry strategy had the average pre-test score of 3.93 and the post-test of 9.32 , while the conventional learning was 2.15 for the pre-test and 6.37 for the post-test (Table 7).

Table 7

Description of the Creating Competence

\begin{tabular}{|c|c|c|c|c|c|c|c|c|c|}
\hline \multirow[b]{2}{*}{ Variable } & \multirow[b]{2}{*}{ Stat. } & \multicolumn{4}{|c|}{ free Inquiry } & \multicolumn{4}{|c|}{ Conventional Teaching } \\
\hline & & $\mathrm{n}$ & $\begin{array}{l}\text { Pre- } \\
\text { test }\end{array}$ & $\begin{array}{l}\text { Post- } \\
\text { test }\end{array}$ & $\mathrm{N}<\mathrm{G}>$ & $\mathrm{n}$ & $\begin{array}{l}\text { Pre- } \\
\text { test }\end{array}$ & $\begin{array}{l}\text { Post- } \\
\text { test }\end{array}$ & $\mathrm{N}\langle\mathrm{G}>$ \\
\hline \multirow{3}{*}{$\begin{array}{l}\text { Creating } \\
\text { competence }\end{array}$} & $\bar{x}$ & \multirow[t]{3}{*}{38} & 10.26 & 87.89 & \multirow[t]{3}{*}{.86} & \multirow[t]{3}{*}{38} & 9.47 & 28.94 & \multirow[t]{3}{*}{.21} \\
\hline & $\%$ & & 20 & 100 & & & 20 & 60 & \\
\hline & $\mathrm{S}$ & & 1.03 & 1.20 & & & 1.06 & 1.76 & \\
\hline
\end{tabular}

The results of Kolmogorov-Smirnov One-Sample test indicated that both pre-test and post-test had significant values of $p=.126>.05$, so that the scores for the both tests 
were not normally distributed. The homogeneity test with Levene test revealed the score of homogeneous variances $(p>.05)$ where the value for the pretest was .724 and the post-test was .182, respectively. The result of the independent sample $t$ test with equal variances assumed (Table 8 ) showed that the free inquiry and the conventional strategy gained different mean score significantly. It indicated the effect of the free inquiry implementation toward the improvement of the students' creating competence $(p=.00<$ $.05)$. It can be seen from Asymp. Sig. (2-tailed) of .596 in pretest value, and .000 in posttest with $(\mathrm{p}=.000<.05)$. So, it can be concluded that the average of creating competency using free inquiry learning is higher than the implementation of conventional strategy.

Table 8

The Result of Independent Sample T-Test of the Creating Competence

\begin{tabular}{lll}
\hline Group & $\mathrm{t}$ & Asymp. Sig. (2-Tailed) \\
\hline Pretest Experiment Control & .533 & .596 \\
\hline Posttest Experiment Control & 27.652 & .000 \\
\hline
\end{tabular}

\section{Description of Structured, Guided, and Free Inquiry Implementation}

This learning model is implementing all learning activities according to the structured learning syntax which is measured with the observational instruments. To examine the reliability of inquiry learning strategy as presented in Figure 4, the analysis results of the reliability from the observations was analyzed with the coefficient formula of Cohen's

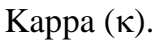

\begin{tabular}{|ccc|}
\hline & 口 Coefficient Cohen Kappa $(\mathrm{K})$ & \\
0,87 & 0,85 & 0,87 \\
\hline $\begin{array}{c}\text { Structured } \\
\text { inquiry }\end{array}$ & $\begin{array}{c}\text { Guided } \\
\text { inquiry }\end{array}$ & $\begin{array}{c}\text { Free } \\
\text { inquiry }\end{array}$ \\
\hline
\end{tabular}

Figure 1

The Reliability Data of the Observations

Explanation:

$\mathrm{K}<0.40 \quad$ : poor

$0.40<\mathrm{k}<0.75 \quad:$ good

$\mathrm{K}>0.75 \quad$ : very good

The Figure 1 above explains the observation results conducted by two observers with the reliability coefficient of 0.87 for structured inquiry; 0.85 for guided inquiry; and 0.87 , for free inquiry, respectively; Those three values can be categorized as very good. The analysis results showed that both observers had similar perceptions as they 
considered the implementation of inquiry model very good and consistent with the expectation of the high stability level.

\section{DISCUSSION}

The analysis of pretest and posttest data showed the gap score between the experimental and the control class where the experimental one was higher. Moreover, the independent sample $\mathrm{t}$-test for both experimental and control class gained the score that was lower than $.05(\mathrm{p}<.05)$. It indicates that there is a significant gap on the scientific reasoning competency for analyzing, evaluating and creating aspects between the experimental class with inquiry learning strategy and the control class with the conventional teaching. The results of the three levels of inquiry learning models showed its effectiveness to enhance the students' scientific reasoning competency for analyzing, evaluating and creating aspects. The improvement of scientific reasoning competency is caused by the lecturers who considered various levels of students' development and learning styles during the learning process. This finding is supported by Zubaidah et al., (2017) who focus on the importance of various inquiry models to accommodate the students' different levels related to their readiness, interest, learning style, and pace in accepting and processing information. It can be used to clarify if the lecturers only apply free inquiry, the students with low competency will find it difficult to follow the lesson. On the other hand, if lecturers implement the structured inquiry, it would be too easy for the students with high competency.

The implementation of the three levels of inquiry to this research is proven effective to enhance the scientific reasoning competency and it is consistent with the previous studies that indicates that each level of inquiry models has different contributions to the improvement of science processing skills (Hardianti \& Kuswanto, 2017). This is consistent with Zion and Mendelovici (2012) theory that the application of structured inquiry contributes to the development of basic skills, such as observation, conclusions formulation, hypothesis formulation, and data collection, while the guided inquiry competency deals with the data collection procedure. In line with this, Fuad et al., (2017), clarify that each inquiry level can contribute to the improvement of different competency. The results of previous studies indicate that the application of open inquiry is more effective in developing various dependent variables, such as cognitive skills, procedural skills, critical thinking, scientific concept understanding and motivation (Zion \& Mendelovici, 2012; Artayasa et al., 2018). These findings are consistent with some previous studies in case of the inquiry model integration, such as Sriarunrasme et al., (2015), Zubaidah et al., (2017) and Yusnaeni et al., (2017). Another study from Aktamis and Higde (2015) on the application of inquiry models for science learning find it significant to improve the students' learning performance, science processing skills and scientific attitude compared to the conventional learning method.

By reviewing several results of the relevant studies above, it can be understood that the inquiry learning models could enhance the students' scientific reasoning skills based on some assumptions, such as experiences in formulating hypothesis, implementing experimental procedure, collecting data, analyzing data and making conclusions. By doing so, the students will be motivated to make scientific argumentation, to understand 
concepts, to enjoy applicable learning method so that the presented materials can be stored in the students' long-term memories. However, the implementation of this inquiry models encountered various obstacles, such as difficulties in designing the experiment, collecting data, handling laboratory tools (Castro \& Morales, 2017; Nidup \& Yodyingyong, 2015; Pewnima et al., 2011). Meanwhile, Subali (2016) points out that some failures may be triggered by the unclear working procedure during the problems solving experiment. These may stimulate wrong response in identifying the involved variables during the learning process.

The description above implies that there are various obstacles to face the learning process, but in this study, the learning activities had shown successful in applying inquiry-based learning with the improvement of students' motivation, interest, investigation technique, knowledge. They can also be directed to think actively and to find a solution for the problems. Based on the research results, the escalation of scientific reasoning competency of analyzing, evaluating and creating aspects is due to the stages of inquiry method by involving cognitive and meta-cognitive activities. In addition, the learning experiences form the mental structure can provide and transform into knowledge (Makarova, Lvona \& Mikhailovna, 2017; Steinberg \& Cormier, 2013; Waldrip, 2012; Uno, 2014). The data of the students' scientific reasoning are relevant to some research results in which the students with higher scientific reasoning can have better problem solving skill, and positively impact their learning results (Lawson, 2004; Marusic, Misurac Zorica \& Pivac, 2012; Ding, 2014; Fabby \& Koenig, 2015; Steinberg \& Cormier, 2013; Perez \& Furman, 2016; Sadeh \& Zion, 2009). So, it can be concluded that the science learning should be able to optimize the students' problem-solving skills through collection of facts, problems analysis, decision making and rational considerations.

The analysis of the observation sheet on syntax implementation of this inquiry model considered "very good" and fulfilled the expectation with high reliability level. The lecturers have been trained to understand various inquiry learning syntaxes applied with full self-reliance and self-efficacy. These conditions are consistent with the studies by Kocagul Saglam and Sahim (2017), Lee and Shea (2016) that emphasizing on science teaching through inquiry, and this part is very crucial in the education process for prospective teachers. The previous studies indicate that the professional development training is an integral part to improve the teachers' reliance, self-efficacy and science processing skills. The students' investigation skills tended to involve various argumentative process and it is consistent with Kabatas Memis and Oz findings in 2014. Moreover, the arguments in the learning is to involve the process of scientific findings. The description is also reviewed in similar studies by Pedaste et al., (2014), that the inquiry-based learning relates students to the authentic scientific finding process, where complex scientific process is classified into smaller parts with mutual relation and they are directed to solve problems based on the facts and proper data. The findings of this study are considered "very good" based on the observations results and it may be caused by lecturers who implement all learning components of and the students obtain learning experiences that is able to develop of creative thinking and communication skills. This point is also consistent with the ideas from Bybee, (1997) and Tompoa et al. (2016). 
Based on the research results, the three inquiry models fall into very good category, but some problems appeared, such as the syntax application, the difficulties to control the students' achievement during the inquiry stages, and time allocation. Therefore, further guidance is needed to master the working procedure in doing experiment to solve problems and to give logical arguments. The application of syntax should also be accompanied with the other parties to make sure its consistency with the behaviour indicator during the inquiry learning.

\section{CONCLUSSIONS AND IMPLICATION}

Based on the research results, some conclusions can be drawn as follows. The strategy in implementing the three levels of inquiry learning is effective to improve the scientific reasoning competency in the aspects of analyzing, evaluating and creating. There is a significant difference in case of its effectiveness between the three levels of inquiry and the conventional method in improving the students' scientific reasoning skills. Moreover, the implementation of the free inquiry ranked as the highest on the scientific reasoning improvement, followed by the guided inquiry, the structured inquiry and the conventional teaching. The application of the three levels of inquiry can be categorized as very good with high reliability level. The implication of this research are expected to give practical contribution as one of alternative choices in improving learning effort, as follows: For students, these increase scientific reasoning skills to be able to decide and behave logically have science literacy. For teachers, this research is expected to function as efforts to make inquiry model of levels of structured inquiry, guided inquiry and free inquiry in implementing the learning process in classroom.

\section{SUGGESTION}

Suggestion of this study are that for next research we offer other strategy for determining the quality of implementation of three levels inquiry such as we can assess by using student's opinion (self-evaluation) on implementation of three levels of inquiry namely using Likert model scale. In addition to the lecturers of biology should have better comprehensive understanding of the hierarchical nature and relations of various pedagogical practices in the inquiry process in order to be effective in teaching science by using the inquiry approach.

\section{REFERENCES}

Aktamış, H., \& Hiğde, E. (2016). Effects of inquiry-based learning method on students' achievements, science process skills and attitudes towards science: A meta-analysis science. Journal of Turkish Science Education, 13(4), 3-23. doi:10.12973/tused.10183a.

Alameddinea M. M., \& Ahwalb, H. W. (2016). Inquiry based teaching in literature classrooms. Procedia-Social and Behavioral Sciences, 232, 332-337. doi:10.1016/j.sbspro.2016.10.031.

Andrini, V. S. (2016). The effectiveness of inquiry learning method to enhance student' learning outcome: a theoretical and empirical review. Journal of Education and Practice,7(3), 38-42. 
Arsal, Z. (2017). The impact of inquiry-based learning on the critical thinking dispositions of pre-service science teachers. International Journal of Science Education, 39(10), 1-11. doi: 10.1080/09500693.2017.1329564.

Arslan, A. (2014). Transition between open and guided inquiry instruction. ProcediaSocial and Behavioral Sciences, 14, 407-412. doi: 10.1016/j.sbspro.2014.05.071.

Artayasa, I P. Susilo, H., Lestari, U., \& Indriwati, S. E. (2018). The effect of three levels of inquiry on the improvement of science concept understanding of elementary school teacher candidates. International Journal of Instruction, 11(2), 235-248. doi:10.12973/iji.2018.11216a.

Ary, D., Jacobs, L. C., Sorensen, C. K., Walker, D. A., \& Razavieh, A. (2010). Introduction to research in education measurement. Wadsworth Publishing.

Asniar. (2016). Profil penalaran ilmiah dan kemampuan berargumentasi mahasiswa sains dan non-sains [The profile of scientific reasoning and the argumentation skill of students from science and non-science]. Jurnal Penelitian dan Pembelajaran IPA, 2(1), $30-41$.

Brookhart, S. M. (2010). How to assess higher-order thinking skills in your classroom. ASCD. Retrieved from http://www.ascd.org/Publications/Books/ Overview/How-to-Assess-Higher-Order-Thinking-Skills-in-YourClassroom.

Bybee, R. W. (1997). Achieving scientific literacy: From purposes to practices. Portsmouth: Heinemann

Castro, J. A. F., \& Morales, M. P. E. (2017). "Yin" in a guided inquiry biology classroom- exploring student challenges and difficulties. Journal of Turkish Science Education,14(4), 48-65. doi:10.12973/tused.10212a.

Ding, L. (2014). Verification of causal influences of reasoning skills and epistemology on physics conceptual learning. Physical Review Special Topics-Physics Education Research, 10(2).1-5. doi:10.1103/PhysRevSTPER.10.023101.

Fabby, C., \& Koenig, K. (2015). Examining the relationship of scientific reasoning with physics problem solving. Journal of STEM Education, 16(4), 20-27.

Fuad, N. M., Zubaidah, S., Mahanal, S., \& Suarsini, E. (2017). Improving junior high schools' critical thinking skills based on test three different models of learning. International Journal of Instruction, 10(1), 101-116. doi:10.12973/iji.2017.1017a.

Gronlund, E., Norman. (1992). Constructing achievement tests. London: Prentice Hall.

Guilford, J. P. (1956). Fundamental statistics in psychology and education. New York: Mc Graw-Hill.

Hardianti, T., \& Kuswanto, H. (2017). Difference among levels of inquiry: process skills improvement at senior high school in Indonesia. International Journal of Instruction, 10(2), 119-130. 
Jeong, J., Kim, H., Chae, D., Hyun, \& Kim, E. (2014). The effect of a case-based reasoning instructional model on Korean high school students' awareness in climate change unit. Eurasia Journal of Mathematics, Science and Technology Education, 10(5), 427-435. doi:10.12973/eurasia.2014.1105a.

Kabatas Memis, E. K., \& Oz., M. (2014). The impact of inquiry process on the cognitive process dimensions of nontraditional writing. Mediterranean Journal of Social Science, 5(20), 1159-1167. doi:10.5901/mjss.2014.v5n20p1158.

Ketpichainarong, W., Panijpan, B., \& Ruenwongsa, P. (2010). Enhanced learning of biotechnology students by an inquiry-based cellulose laboratory. International Journal of Environmental \& Science Education, 5(2), 169-187.

Kocagul Saglam, M., \& Sahin, M. (2017). Inquiry-based professional development practices for science teachers. Journal of Turkish Science Education, 14(4). 66-76. doi:10.12973/tused.10213a.

Lawson, A. E. (2004) The nature and development of scientific reasoning: A synthetic view. International Journal of Science and Mathematics Education, 2, 307-338. doi:10.1007/s10763-004-3224-2.

Lee, C. K., \& Shea, M. (2016). An analysis of pre-service elementary teachers' understanding of inquiry-based science teaching. Science Education International, 27(2), 217-237.

Linn, R. L. (1989). Educational measurement. New York: Macmillan Publishing Company.

Llewellyn, D. (2013). Teaching high school science through inquiry and argumentation. California: Corwin A Sage Company.

Lohman, D. F., \& Lakin, J. M. (2010). Intelligence and reasoning. In R. J. Stemberg, \& S. B. Kaufman (Eds.), The Cambridge handbook of intelligence (pp. 419-441). New York, NY: Cambridge University Press.

Mäeots, M., \& Pedaste, M. (2014). The role of general inquiry knowledge in enhancing students' transformative inquiry processes in a web-based learning environment. Journal of Baltic Science Education, 13(1), 19-32.

Makarova, A., Lvovna, M., \& Mikhailovna, V. (2017). Education process visualization in metacognition development and sustainability. International Journal of Cognitive Research in Science, Engineering and Education, 5 (2), 65-74. doi:10.5937/ijcrsee1702065A.

Martin-Gamez, C., Prieto-Ruz, T., \& Jimenez-Lopez, M. A. (2016). Developing preservice science teachers' beliefs about new approaches to science education. Journal of Turkish Science Education, 13(4), 123-136. doi:10.12973/tused.10181a. 
Marušić, M., Mišurac Zorica, I., \& Pivac, S. (2012). Influence of learning physics by reading and learning physics by doing on the shift in level of scientific reasoning. Journal of Turkish Science Education, 9(1), 146-161.

Moore, J. C., \& Rubbo, L. J. (2012). Scientific reasoning abilities of nonscience majors in physics-based courses. Physical Review Special Topics-Physics Education Research, 8(1), 010106. doi: 10.1103/PhysRevSTPER.8.010106.

Nidup, T., \& Yodyingyong, S. (March, 2015). Inexperience students' perception, difficulties and challenges towards implementation of lab-based inquiry approach: A case study in Bhutan. Paper presented at the Proceeding of the 3rd Global Summit on Education GSE, Kuala Lumpur, Malaysia.

Nieminen, P., Savinainen, A., \& Viiri, J. (2012). Relations between representational consistency, conceptual understanding of the force concept, and scientific reasoning. Physical Review Special Topics-Physics Education Research, 8(1), 010123. doi: 10.1103/PhysRevSTPER.8.010123.

Novkovic-Cvetkovic, B., \& Stanojevic, D. (2017). Educational needs of teacher for introduction and application of innovative models in educational work to improve teaching. International Journal of Cognitive Research in Science, Engineering and Education, 5(1), 49-56. doi:10.5937/IJCRSEE1701049N.

OECD. (2016). PISA 2015 result in focus. Retrieved from https://www.oecd.org.

Opitz, A., Heene, M., \& Fischer, F. (2017). Measuring scientific reasoning - A review of test instruments. Educational Research and Evaluation, 23(3-4),78-101. doi:10.1080/13803611.2017.1338586.

Osborne, J., \& Kind, P. (2017). Styles of scientific reasoning: a cultural rationale for science education. Science Education, 101(1), 8-31. doi:10.1002/sce.21251.

Partanto, A. P., \& Al Barry, D. M. (1994). Kamus ilmiah popular [Popular scientific dictionary]. Surabaya: Arkola.

Pedaste, M., Mäeots, M., Siiman, L.A., \& Ton de Jong. (2015). Phases of inquiry-based learning: Definitions and the inquiry cycle. Educational Researc,14(1), 47-61. doi:10.1016/j.edurev.2015.02.003.

Pérez, M.del C. B., \& Furman, M. (2016). What is a scientific experiment? the impact of a professional development course on teachers' ability to design an inquiry-based science curriculum. International Journal of Environmental \& Science Education, 11(6), 1387-1401. doi:10.12973/ijese.2016.353a.

Pewnima, K., Ketpichainaronga, W., Panijpanb, B., \& Ruenwongsaa, P. (2011). Creating young scientists through community science projects. Procedia Social and Behavioral Sciences, 15, 2956-2962. doi:10.1016/j.sbspro.2011.04.222.

Probosari, R. M., Ramli, M., \& Sajidan. (2015). Dampak pembelajaran inkuiri berjenjang dalam meningkatkan keterampilan menulis argumentatif calon guru [Impact 
of hierarchy of inquiry learning in improving skills of writing argumentative teachers]. Jurnal Pengajaran MIPA, 20(2),155-162. doi: 10.18269/jpmipa.v20i2.579.

Ramnarain, U., \& Hlatswayo, M. (2018). Teacher beliefs and attitudes about inquirybased learning in a rural school district in South Africa. South African Journal of Education, 38(1), 1-10. doi:10.15700/saje.v38n1a1431.

Sadeh, I., \& Zion, M. (2009). The development of dynamic inquiry performances within an open inquiry setting: a comparison to guided inquiry setting. Journal of Research in Science Teaching, 46(10), 1137-1160. doi:10.1002/tea.20310.

Sahyar, \& Hastini, F. (2017). The effect of scientific inquiry learning model based on conceptual change on physics cognitive competence and science process skill (SPS) of students at senior high school. Journal of Education and Practice, 8(5), 120-126.

Saptono, S., Rustaman, N., Saefudin, \& Widodo, A. (2013). Model integrasi atribut asesmen formatif (IAAF) dalam pembelajaran biologi sel untuk mengembangkan kemampuan penalaran dan berpikir analitik mahasiswa calon guru [Model of integration of formative assessment attributes (IAAF) in Cell Biology learning to develop reasoning skills and analytical thinking Biology student teachers]. Jurnal Pendidikan IPA Indonesia, 2(1), 31-40.

Shaw, V. F. (2010). The cognitive processes in informal reasoning. Thinking \& Reasoning, 51-80. doi: 10.1080/135467896394564.

Sriarunrasmee, J., Suwannatthachote, P., \& Dachakupt, P. (2015). Virtual field trips with inquiry learning and critical thinking process: a learning model to enhance students' science learning outcomes. Procedia-Social and Behavioral Sciences, 197, 1721-1726. doi:10.1016/j.sbspro.2015.07.226.

Steinberg, R., \& Cormier, S. (2013). Understanding and affecting science teacher candidates' scientific reasoning in introductory astrophysics. Physical Review Special Topics-Physics Education Research, 9(2), 1-10. doi:10.1103/PhysRevSTPER.9.020111.

Stephens, A. L., \& Clement, J. J. (2010). Documenting the use of expert scientific reasoning processes by high school physics students. Physical Review Special Topics Physics Education Research, 6(2), 1-15. doi:10.1103/PhysRevSTPER.6.020122.

Subali, B. (2016). Prinsip asesmen dan evaluasi pembelajaran [Principles of assessment and evaluation of learning]. Yogyakarta: UNY Press.

Thummathong, R., \& Thathong, K. (2016). Construction of a chemical literacy test for engineering students. Journal of Turkish Science Education, 13(3), 185-198. doi:10.12973/tused.10179a.

Tompoa, B., Ahmad, A., \& Murisa, M. (2016). The development of discovery-inquiry learning model to reduce the science misconceptions of junior high school students. International Journal of Environmental \& Science Education, 11(12), 5676-5686.

Uno, H. B. (2014). Model pembelajaran menciptakan proses belajar mengajar yang 
kreatif dan efektif [The learning model creates a creative and effective teaching and learning process]. Jakarta: bumi aksara.

Utomo, A. P., Narulita, E., \& Shimizu, K. (2018). Diversification of reasoning science test items of TIMSS grade 8 based on higher order thinking skills: A case study of Indonesian students. Journal of Baltic Science Education, 17(1),152-161.

Uum, M. S. J. Van, Verhoeff, R. P., \& Peeters, M. (2017). Inquiry-based science education: Scaffolding pupils' self-directed learning in open inquiry. International Journal of Science Education, 39(18), 2461-2481. doi:10.1080/09500693.2017.1388940.

Waldrip, B. (2012). Reasoning through representing in school science. Teaching Science, $58,14-18$.

Wenning, C. J. (2011). The levels of inquiry model of science teaching. Journal of Physics Teacher Education Online, 6(2), 9-16.

Yanto, B. E. (2016). Application of problem-based learning and inquiry to gain creative thinking and mastery of concepts. Paper presented at the $3^{\text {rd }}$ International Conference on Research, Implementation and Education of Mathematics and Science, Yogyakarta.

Yanto, B. E., Subali, B., \& Suyanto, S. (2019). Measurement instrument of scientific reasoning test for biology education students. International Journal of Instruction, 12(1), 1383-1398. doi:10.29333/iji.2019.12188a.

Yusnaeni, Corebima, A. D., Susilo, H., \& Zubaidah, S. (2017). Creative thinking of low academic student undergoing search solve create and share learning integrated with metacognitive strategy. International Journal of Instruction, 10(2), 245-262.

Zion, M., \& Mendelovici, R. (2012). Moving from structured to open inquiry: challenges and limits. Science Education International, 23(4), 383-399.

Zubaidah, S., Fuad, N. M., Mahanal, S., \& Suarsini, E. (2017). Improving creative thinking skills of students through Differentiated Science Inquiry integrated with mind map. Journal of Turkish Science Education, 14(4), 77-91. doi:10.12973/tused.10214a). 